\title{
Organisational Pressure on Quality-of-Worklife of Academic and Non- Academic Women Workers in Tertiary Institutions in Lagos State, Nigeria
}

\author{
Prof. Mobolaji Ogunsanya \\ Department of Educational Management, University of Ibadan \\ Tel: 234-80-2431-5745_E-mail: mobolajiogunsanya@yahoo.com \\ Dr. Adebisi Olorunfemi (corresponding author) \\ Department of Educational Management, Lagos State University, Ojo \\ Tel: 234-80-8098-4578Ｅ-mail: bisiyinka@gmail.com
}

Received: May 16, 2012 Accepted: June 4, 2012 Published: August 1, 2012

doi:10.5296/jse.v2i3.1810 URL: http://dx.doi.org/10.5296/jse.v2i3.1810

\begin{abstract}
An approach to motivation in the contemporary world of work is the implementation of Quality-of-Worklife (QWL) programmes, which is aimed at easing the pressures faced at work by employees. Quality-of-Worklife is a relatively new concept in human resource management. It is a philosophy of improving productivity by providing workers with the opportunities required to put in their best at work, without jeopardizing their personal self improvement and responsibilities at home. This study, investigated the organisational pressure on Quality-of-Worklife of academic and non - academic women in tertiary institutions in Lagos State, Nigeria. The study was a survey of the ex-post facto type. 3,640 senior cadre women working in the four purposively selected degree awarding institutions in Lagos State (University of Lagos, Lagos University Teaching Hospital, Lagos State University and Lagos State University Teaching Hospital) and their managers formed the population. Out of these, 250 women were selected as sample from each institution using the stratified random sampling technique. Three instruments were used for the study: Quality-of-Worklife survey of Women Workers (QWLSWW) $\mathrm{r}=.815$, Head of Department Check List (HODCL) and Structured Interview Questions (SIQ). A research question and 3 research hypotheses were tested at 0.05 significance level. Data were analysed using frequency counts, percentages, $t$-test. Significant differences were found between academic and non-academic female members of staff in their sources of pressure $(\mathrm{t}=2.43, \mathrm{P}<0.05)$. The
\end{abstract}


factors included: salary, health-care benefits, day-care services on workplace premises and workload. However, no significant differences were found between academic and non-academic female members of staff on sources of satisfaction which included, daily workload, salary, fairness in performance assessment, special recognition for high performance, internet facilities at work and health- care benefit and organisational pressure factors. Factors such as salary, health-care benefit, day-care services, recognition, workload and others influenced QWL of women. Government and management committees of the tertiary institutions should ensure the reduction of organisational pressure and promote high QWL. This would enable the women workers contribute to the productivity of their organisation.

Keywords: Quality-of-worklife, Academic, Non-academic, Organisational pressure, Sources of pressure, Sources of satisfaction, productivity, Nigeria 


\section{Introduction}

The worklife of an employee is as important as living because a considerable amount of one's day is spent at the workplace. As the times are changing and improved technologies brings about sophistication, there is a need to improve on workers' worklife. The desire for a better work environment raised the need to be motivated on the side of the employee. However, the owners of the organisations also face a tightening competition or challenge to improve on their productivity, hence the desire to raise the performance of the workers. Invariably, both the employees and the employers desire motivation for improved worklife and improved organisational performance. Motivation is a pervasive function that cuts across all aspects of employee's development. The creation of a conducive working environment is a prerequisite for achievement of organisational success. Hence, it is necessary for managers to understand what motivates workers and how motivation influences work performance, since motivation denotes relationship between needs and the fulfilments of needs

One of the most interesting approaches to motivation is the 'Quality-Of-Worklife (QWL) Programmes into the work system. According to Weihrich and Koontz (1994), "QWL is a systems approach to job design and a promising development in the broad area of job enrichment, combined with grounding in the socio-technical systems approach to management"..

It is being increasingly accepted as noted by Oshionebo (1992) that, "human affective experience is important for its own sake and that material possessions and economic growth do not necessarily produce a high quality of life". The indicators of quality-of-worklife includes; adequate and fair compensation, job satisfaction, workers' participation in decision-making and problem-solving, safe and healthy work environment, adequate career development, social integration, growth and security. The absence or inadequate presence of these indicators leads to the increasing stress at work. The World Labour Report asserted that stress has become one of the most serious health issues, creating much financial damage to employers and governments ( as cited in Martino 1993).

Some countries are introducing QWL programmes as a means of alleviating the problems of women at the workplace, but not much is done in Nigeria yet. Hence, this study is geared towards; examining the quality-of-worklife of women working in tertiary institutions in Lagos State, identifying how some organisational factors influence their QWL, and comparing the academic and non- academic staff members.

\subsection{Statement of the Problem}

'Worklife' is the forward-thinking efforts that employers are taking to provide policies and programmes that foster a supportive workplace environment, in order to help employees achieve balance in the often competing priorities of their work lives and private lives. The question is, how much effort has the Nigerian government and employers put in this direction? In spite of the various International Labour Organisation (ILO) conventions and recommendations made in favour of women workers, considering the role stereotyping that makes women face the challenges of 'Work-life balance' the most, the problems still persists 
world-wide, especially in developing countries like Nigeria. More prominent among the problems of most women at work is exerting themselves in combining work and home responsibilities and at the same time aspire towards self-actualization in their career. The tertiary institutions have a large population of women workers cutting across both the academic and non -academic staff. There is the notion or belief that the QWL is generally higher among the latter than the former, due to the possible higher organisational pressure faced by the former.

\subsection{Research Questions}

The following research question is to act as a guide for this study;

1. Is there any difference in the QWL of academic and non-academic women workers in tertiary institutions in Lagos State?

\subsection{Hypotheses}

1. There is no significant difference in the sources of pressure faced by academic and non-academic female staff in tertiary institutions in Lagos State.

2. There is no significant difference in the sources of satisfaction enjoyed by academic and non-academic female staff in tertiary institutions in Lagos State.

3. There is no significant difference in the organisational pressure experienced by academic and non-academic female staff of tertiary institutions in Lagos State.

\section{Literature Review}

The human resources has been tagged as the most important factor of production in an organisation, be it service industries or commercial. It then calls for the need to work assiduously towards maintaining and developing them in order to get the required or expected level of productivity. It has been observed that a lot of extraneous factors do work against the high productivity of workers. Some of these factors could be classified as; natural impediments such as the family responsibilities, the level of social interaction with co-workers within the organisation, societal responsibilities, economical and political. At times all these can amount to pressures on the worker, creating stress, impact negatively on the level of job satisfaction and affecting the quality-of-worklife. The resultant effect would invariably be poor job performance and low productivity.

The United Nations Department of Economic And Social Affairs, Division for Sustainable Development (2004) in a study of Nairobi, concluded that, in order to achieve full, equal and beneficial integration of women in all development activities, there must be, "programme to promote the reduction of the heavy workload of women and girl children at home and outside, through the establishment of more and affordable nurseries and kindergartens ---- social support systems and services, including day-care facilities and parental leave have to be put in place by the government, employers and other relevant organisations". This is applicable to the Nigerian situation also. 
Giving short deadlines for the completion of jobs could come up as source of organisational stress. When there is heavy workload due to shortage of workers, and the urgency to complete the work within a stipulated time, there is the tendency that high productivity might not be achieved.

Amabile (2002) in a longitudinal study lasting fourteen years discovered that time pressure do not have effect on the creativity of workers positively. It was thus suggested that if creativity is to be encouraged, among other impediments, time pressure has to be eliminated.

In a survey conducted on QWL in Canada by Duxbury and Higgins (2005) it was found that one of the major organisational factors that puts so much pressure on the level of QWL of women workers is the role overload. This is referred to as the number of hours one puts in per day: meanwhile the workplace culture encourages long-hours of work including unpaid overtime. Any worker who does not put in such long hours is tagged and looses rewards, such as promotion. It is obvious that women workers will be most affected by this workplace culture because they might not be so willing to put in unpaid overtime while they have family responsibilities to equally attend to. Hence, the male workers will be getting rewarded with promotion while the female workers get stagnated.

Another major organisational factor impinging on QWL is the work-scheduling. The traditional eight hours per day work hours, has been found not to contribute to high performance on the part of some workers. Such workers, either on health grounds or domestic demands, cannot put in the required eight hours or fit into the scheduled time frame. They would engage in much more lateness, absenteeism, escapism and sick leave, than normal. It is reported that many companies have found out that coming up with programmes to help employees balance work with outside needs, pressures and interest, can make them realize benefits in increased productivity and reduced turnover (Business for Social Responsibility, 2005). In a study conducted by American Business Collaboration (2006) it was discovered that after the salary, the factor next to job satisfaction for people in their $30 \mathrm{~s}$, was flexible work options for salaried men, while salaried women opted for worklife balance which of course will include flexibility in the work schedule.

Policies and organisational rules are meant to guide workers on their job activities, such that work environment could experience a peaceful climate. However, it has been observed that many a times, rather than these organisational policies engendering peace, they tend towards crisis, disaffection and ultimately low productivity. The reasons attributed to the negative impact of these policies include, the decision-making process and the communication system. It has been observed that issues concerning women at work do not usually receive much of women's involvement in the decisions on it. For instance, Niombo (2006) reported that, 'worldwide, women are under-represented in all decision making structures on information communication technologies (ICT) regulations and policy institutions, ICT ministries and management boards in private companies". It was concluded that there should be efforts at building women's capacity to control the decisions that affect their lives.

In the findings of Martin (2006), the usefulness of QWL in resolving industrial relations problems has become very evident in California State University. It is noted that the future of 
public sector labour unions and management is one of increased collaboration. However, it has been observed that, during the past two decades, public sector and management have continually been at divergence over issues relating to compensation, benefits, overtime, and so forth. Naturally, agreeable accommodation for both parties has been difficult to achieve. It is cognizant of this problem that public labour unions and government agencies have begun to implement QWL programmes in order to help mitigate negotiation issues; this has recorded high level of success in Western Europe, Japan and United States. In his submission, Matanmi (2007) concluded that employment relationships in Nigeria's complex organisations will endure, particularly when such relationships are founded on some parameters which includes; equity and fairness, humanistic working conditions and environment, a prevalent employment practice in the work organisations that are primarily targeted at the attainment of QWL, the embrace of flexibility in collective relations such as the choice of more deregulated/decentralized structures of workplace management, a faithful attention by operators and managers of formal work organisations to the work organisational factors.

According to the Business for Social Responsibilities (2006), Work Life Quality Programmes can increase productivity. It states that studies have shown that programme which help employees to balance work and their lives outside work can improve overall productivity. It stressed further that a company's recognition and support (through its stated values and policies) of employee's outside commitments, interests and pressures can help to relieve employees' external stress. This allows them to focus on their jobs during the workday and helps to minimize absenteeism. The result can be both enhanced productivity and strengthened employee commitment and loyalty. It is imperative for definite moves to be made in the direction of studying the works that have been done and those still ongoing, in order for the Nigerian workers to move along with the global trends in the areas of Worklife Quality. This is because it is no gainsaying that, good QWL programmes are proven to have a positive impact on work productivity and are an important factor in recruiting and retaining the very best workers.

\section{Research Design And Methodology}

This study adopted a descriptive survey research of the ex-post facto type. The population was made up of all the 3,640 women of senior staff cadre, working in the government owned degree awarding tertiary institutions in Lagos state. Also forming part of the study population are the head of departments and management level officers in those institutions.

The sample elements for this study were the two universities and the two teaching hospitals situated in Lagos, making a total of four institutions, namely, Lagos State University Teaching Hospital (LASUTH), Lagos University Teaching Hospital (LUTH), Lagos State University (LASU) and University of Lagos (UNILAG). From the population of women workers in these selected institutions, 250 were randomly selected from each institution, making a total of 1000 women for the study.

The multi-stage sampling method was adopted. The purposive sampling technique was used in selecting the institutions. The participants were selected by convenience, using the simple 
random sampling technique. However, only 715 copies of the questionnaire were returned which was $71.5 \%$ of the expected returns.

Three levels of data collection were adopted. First is the survey questionnaire titled, 'Quality-of-Worklife Survey of Women Workers (QWLSWW). The 61 item questionnaire was sub-divided into five sections. While section A addressed the biodata of the respondents, Sections B to E required the respondents to respond to statements using a four point Likert Scale response format, looking at the relevant factors: sources of pressure, sources of satisfaction, compliance to ILO recommendations and conventions that are peculiar to women and organisational pressure factors that could influence the productivity of respondents.

The second level of data collection was by observation. The head of each selected department was asked to tick a checklist on the various characteristics that expresses the level of QWL exhibited by women workers under their supervision. There were 18 characteristics which each H.O.D was to rate for each observed female worker within the study sample. The rating was from five to one, with five being highest and one lowest in scoring.

The third level of data collection instrument was a structured interview conducted on some management level officers of the institutions under study.

The pilot study conducted was aimed at getting the validity rate, the reliability rate, and the internal consistencies among the different sections. The factor analysis was carried out using Cronbach Coefficient Alpha, in order to get the factor loading for each item. Furthermore, a test- retest was conducted and the correlation analysis showed that the first and second tests were significantly related at $r=.815$ coefficient. The hypotheses were tested using t-test.

\section{Presentation of Results and Discussion}

715 female workers responded to the questionnaire, rather than 1000 expected. From the 715, UNILAG had 168, while 151 were from LASUTH, 233 from LUTH and 163 from LASU. These respondents were further stratified into 595 non-academic and 120 academic female workers. Also,115 head of departments / supervisors filled the observation checklist and 19 management level officers were interviewed

Since the majority of respondents disagreed with relevant factors as being a disturbance to their productivity and did not find certain relevant factors as a source of pressure at work, then it could be concluded that the women workers are, to a great extent, combining home and work responsibilities. They positively responded to; the opportunity to work independently, have day-care facilities located within work premises, and the allowing of nursing mothers to breastfeed their babies twice a day during a thirty minutes break each time. This shows that the women themselves are not ignorant of their entitlements as directed by the ILO conventions. However, they have not significantly enjoyed some other QWL facilities such as; access to internet that is funded by their organisation, health care benefits and special recognition for high performance. 


\section{Macrothink}

This outcome was supported largely by the response of the management level officers who agreed to the fact that flexible time of work is not officially allowed, even-though there could be private arrangements especially for those running shifts, and the academic staff. Also, only two out of the four institutions do recognize workers who are outstanding, while 'Family Day' for all workers is not in place yet.

\subsection{Hypotheses Testing}

To test the hypotheses, the data generated from the questionnaire QWLSWW becomes relevant. The t-test statistical tool was applied. The decision rule was; at $\mathrm{P}(0.05)$ and degree of freedom (df) 713, if $t$ calculated $\leq t$ table, then accept Ho, if not, do not accept.

$\mathrm{H}_{\mathbf{0}}{ }^{1}$ : There is no significant difference in the sources of pressure faced by academic and non academic female staff of tertiary institutions in Lagos State.

$\mathrm{t}$ table $=\mathrm{t} \alpha(0.013)<.05, \mathrm{df}=713=1.96$

t calculated $=2.479$

Table1. The Summary For T-test Calculations On Differences Between Academic and Non-Academic Female Staff Of Tertiary Institutions On The Sources Of Pressure.

\begin{tabular}{|l|l|l|l|l|l|l|}
\hline Nature of Job & Sample & $\begin{array}{l}\text { Mean of } \\
\text { Response }\end{array}$ & $\begin{array}{l}\text { Standard } \\
\text { Deviation }\end{array}$ & $\begin{array}{l}\text { Calculated } \\
\text { t-value }\end{array}$ & df & $\begin{array}{l}\text { Significant } \\
\text { level }\end{array}$ \\
\hline Non-Academic & 595 & 21.7832 & 6.94992 & 2.479 & 713 & .013 \\
\hline Academic & 120 & 23.5000 & 6.78372 & & & \\
\hline
\end{tabular}

Decision: Since the calculated $\mathrm{t}$ value is greater than the table $\mathrm{t}$ value, the Ho is not accepted.

$\mathbf{H}_{\mathbf{0}}{ }^{2}$ : There is no significant difference in the sources of satisfaction enjoyed by academic and non-academic female staff of tertiary institutions in Lagos State.

$\mathrm{t}$ table $=\mathrm{t} \alpha(0.053)=.05, \mathrm{df}=713=1.96$

t calculated $=1.941$

Table 2. T-test Result of Significant Differences Between Non-Academic and Academic Female Staff of Tertiary Institutions on Sources of Satisfaction.

\begin{tabular}{|l|l|l|l|l|l|l|}
\hline Nature of Job & Sample & $\begin{array}{l}\text { Mean of } \\
\text { Response }\end{array}$ & $\begin{array}{l}\text { Standard } \\
\text { Deviation }\end{array}$ & $\begin{array}{l}\text { Calculated } \\
\text { t-value }\end{array}$ & df & $\begin{array}{l}\text { Significant } \\
\text { level }\end{array}$ \\
\hline Non-Academic & 595 & 41.2185 & 8.03320 & 1.941 & 713 & 0.53 \\
\hline
\end{tabular}




\begin{tabular}{|l|l|l|l|l|l|l|}
\hline Academic & 120 & 39.6667 & 7.77340 & & & \\
\hline
\end{tabular}

Decision: Since the calculated $t$ is less than the critical $t$, it means significant difference is not found, thus, Ho is accepted.

$\mathrm{H}_{\mathbf{0}}{ }^{3}$ : There is no significant difference in the organisational pressure experienced by academic and non-academic female staff of tertiary institutions in Lagos State.

t table $: \mathrm{t} \alpha((.150)>.05, \mathrm{df}=713=1.96$

$\mathrm{t}$ calculated $=1.440$

Table 3. T-test Of Significant Difference Between Non-Academic and Academic Female Staff of Tertiary Institutions On Organisational Pressure Factors.

\begin{tabular}{|l|l|l|l|l|l|l|}
\hline Nature of Job & Sample & $\begin{array}{l}\text { Mean of } \\
\text { Response }\end{array}$ & $\begin{array}{l}\text { Standard } \\
\text { Deviation }\end{array}$ & $\begin{array}{l}\text { Calculated } \\
\text { t-value }\end{array}$ & df & $\begin{array}{l}\text { Significant } \\
\text { level }\end{array}$ \\
\hline Non-Academic & 595 & 35.7697 & 11.70308 & 1.440 & 713 & 0.15 \\
\hline Academic & 120 & 37.4583 & 11.81218 & & & \\
\hline
\end{tabular}

Decision: Since the calculated $t$ is less than the critical table $t$, it means significant difference is not found, thus $\mathrm{H}_{\mathrm{o}}$ is accepted.

The fact that both academic and non-academic staff of tertiary institutions faces QWL challenges is not peculiar to Lagos State or Nigeria. University of California (1998) highlighted, at a symposium on work/life, the central contribution non-academic staff make in supporting the University's academic and research endeavours, and emphasized that 'burnout' from work and home stress is likely to occur most among non-academic staff. This could be an explanation for why there is a significant difference between the two groups of workers in the area of sources of pressure. A similar study was carried out at the George Mason University, U.S.A. The outcome was reported by Buffardi, Papazoglou and Morrison (2000) and it was clearly outlined that even-though there were areas of similarity in the sources of dissatisfaction (pressure) and satisfaction, yet there were peculiarities characterizing the two groups of workers, that is, academic and non-academic workers. The same picture was painted in the study reports of Duke University (2003) Vanderbilt Medical Center as reported by Wood (2003) and the University of Pennsylvania (2005). From all these reports and the outcome of this study, it could be said that all women workers need 
attention on how to achieve high QWL, regardless of their status or area of specialization. However, their peculiarities should also be considered.

\section{Conclusion and Recommendations}

It could be concluded from this study, that there is a great deal of difference between the academic staff and non-academic staff of tertiary institutions, in the sources of pressure they are faced with. This indicates that, the factors that make up sources of pressure for academic staff are not same for non-academic staff. On the other hand, it could be said conclusively that both academic and non-academic female workers of tertiary institutions in Lagos State, do not differ significantly in their sources of satisfaction at work and their sources of organisational pressure.

In the light of the above findings, it is being recommended that, Laws should be enacted, making compulsory the introduction of QWL programmes into the workplace and the establishment of QWL units within the human resources department. Moreover, a regular survey of the QWL of workers and particularly the women workers should be carried out in government parastatals. Most importantly, is the policy of creating enabling environment for the practice of QWL programmes, for it to be successful.

\section{References}

------. (1998). 1998 UC Worklife Symposium, University Of California Publication. [online]Available: http:///www.ucop.edu/worklife/news/news.html

------. (2006). "Work-Life Quality” in Business for Social Responsibility [online] Available: http:www.bsr.org/CSR Resources? Issue Brief Detail. Cfm? DocumentID-50965

------. (2006). American Business Collaboration For Quality Dependent Care. [online]Available: http://www.abcdependentcare.com/docs/current-news.shtml

Amabile, T. (2002). Time pressure and creativity: why time is not on your side. Working knowledge for business leaders.[online]Available: http:hbswk.hbs.edu/item/3030.html.28/8/2006

Buffardi, L. Papazoglou, D., \& Morrison, M. (2000). Findings from the quality of work life survey of George Mason University employees. [online]Available: http://www.gmu.edu/qwl/archive/qw100

Duxbury, L., \& Higgins, C.( 2005). Report four: who is at risk? predictors of work-life conflict.[online]Available:http://www.phac-aspc.gc.ca/publicat/travail/report/index.html

Martin, E. J. (2006). Labour-management relations, collective bargaining, and the public sector collaborative solutions in Alameda, California. Public Administration Quarterly 13. .[online]Available: http://www.pamij.cm/8-2/pam8-2-2.html

Martino, V. D. ( 1993). Cutting the cost of stress. World of Work Magazine, No. 2 Feb. 1993, Geneva; ILO. 


\section{Macrothink}

Matanmi, O. O. (2007). Employment relations that endure: lesson for Nigeria. $31^{\text {st }}$ Inaugural Lecture, Lagos State University.

Niombo, S. (2006). Why Are Congolese Women Absent from Decision-Making in ICTS?” in APC African-Women Programme. [Online] Available: http:www.genderit.org/en/index.shtml

Oshionebo, M.E. (1992). New Trends in Personnel Management: Quality Of Worklife, Lagos: ASCON Publications.

Pennsylvania Human Resources [online] Available: http://www.hr.Upenn.edu/quality/history.asp

UN Department of Economics and Social Affairs. Division for Sustainable Development (2004) 'Global Action for Women towards Sustainable and Equitable Development'. [online]Available: http://www.un.org/esa/sustdev/documents/agenda21/english/agenda21 chapter $24 . h t m$

Unauthored. (2005). History Of Quality Of Worklife At Penn, a publication of University of Weihrich, H \& Koontz, H. (1994) Management: A Global Perspective $10^{\text {th }}$ ed. New York: Mcgraw-Hill, International Edition.

Wood, W. (2003). Quality of Work life Gives Recommendations: Some Changes Already in the Works in The Reporter, publication of Vanderbilt University Medical Centre. [online] Available: http://www.mc.Vanderbilt.edu/reporter/index.html?ID=2735. 